\title{
Pengaruh Customer Relationship Management Terhadap Loyalitas Pelanggan TV Kabel di Kecamatan Tembalang Melalui Kepuasan Pelanggan Sebagai Variabel Intervening (Studi Pada PT. MNC Sky Vision-Indovision Semarang)
}

\author{
Nurul Ulfa Zahroo, ${ }^{1, *}$, Bulan Prabawani ${ }^{2}$ \\ *Departemen Administrasi Bisnis, Fakultas Ilmu Sosial dan Ilmu Politik, Universitas Diponegoro \\ *E-mail: zahroulfa.nura@gmail.com
}

\begin{abstract}
PT. Euro Management Indonesia have some low level performance of employees such as not good in giving directives or guidance or work orders, some work space is not adequate, and the achievement of quality and quantity targets that have not maximized. It is allegedly due to the existence of interpersonal communication and work environment employees are still considered not good. The aims of this study to determine how the influence that given by interpersonal communication and work environment to the performance of employees of PT. Euro Management Indonesia. Type of this research is explanatory research, with 50 respondents of samples. Used questionnaire as data collecting with Likert measurement scale. In the data analysis method used is test of validity and reliability, correlation coefficient $(R)$, regression test, coefficient of determination $\left(R^{2}\right)$, significance of $t$ test and $F$ test by using SPSS 20.0. The results of this research shows that interpersonal communication and work environment severally has significant, strong and positive influence toward employee performance. Two variables has been tested gradually or even together show that interpersonal communication $(0,682)$ and work environment $(0,678)$ simultaneously have strong relation with employee performance. The amount of contribution value $\left(R^{2}\right)$ by interpersonal communication is greater than work environment, coefficient of determination value $\left(R^{2}\right)$ for interpersonal communication is $46,5 \%$ and work environment is $46 \%$.
\end{abstract}

\begin{abstract}
Abstraksi PT. Euro Management Indonesia memiliki tingkat kinerja beberapa karyawan rendah seperti pemberian arahan/bimbingan/perintah kerja yang kurang baik, beberapa ruangan kerja yang masih belum memadai, dan pencapaian target kualitas maupun kuantitas yang belum maksimal. Hal ini diduga karena terdapat komunikasi interpersonal dan lingkungan kerja karyawan yang dinilai masih kurang baik. Penelitian ini bertujuan untuk mengetahui pengaruh yang diberikan oleh komunikasi interpersonal dan lingkungan kerja terhadap kinerja karyawan PT. Euro Management Indonesia. Tipe penelitian yang digunakan adalah tipe penjelasan (eksplanatory research), dengan jumlah sampel sebanyak 50 responden. Pengumpulan data menggunakan kuesioner dengan skala pengukuran likert. Metode analisis data yang digunakan adalah uji validitas dan reliabilitas, koefisien korelasi (R), uji regresi, koefisien determinasi $\left(\mathrm{R}^{2}\right)$, signifikansi uji t dan uji F dengan aplikasi SPSS 20.0. Hasil penelitian ini menunjukan bahwa variabel komunikasi interpersonal dan lingkungan kerja memiliki pengaruh yang signifikan, kuat dan positif terhadap kinerja karyawan. Dua variabel telah diuji secara bertahap maupun bersama-sama menunjukkan hasil bahwa variabel komunikasi interpersonal $(0,682)$ dan lingkungan kerja $(0,678)$ secara simultan memiliki hubungan yang kuat terhadap variabel kinerja karyawan. Besarnya sumbangan yang dimiliki oleh variabel komunikasi interpersonal lebih besar dari besaran sumbangan pengaruh yang dimiliki oleh lingkungan kerja, nilai koefisien determinasi $\left(\mathrm{R}^{2}\right)$ untuk variabel komunikasi interpersonal sebesar $46,5 \%$ dan lingkungan kerja sebesar $46 \%$.
\end{abstract}

Keywords: Employee Performance; Interpersonal Communication; Work Environment

\section{Pendahuluan}

Perkembangan dunia pemasaran pada saat ini menjanjikan suatu peluang dan tantangan bisnis untuk mendapatkan keuntungan lebih. Perkembangan dunia bisnis yang semakin kompetitif dari tahun ke tahun juga dialami oleh perusahaan TV kabel yang ada di Indonesia.
Kemajuan Kota Semarang sampai dengan sekarang semakin nyata dengan semakin membanjirnya produk-produk jasa pelayanan yang ditawarkan produsen dan mudah ditemukan baik dalam pasar modern maupun tradisional. Begitu juga dengan kehadiran TV kabel yang menyemarakkan dinamika kehidupan masyarakat kota Semarang yang semakin modern. Perusahaan yang bergerak dalam layanan TV kabel juga tidak lepas dari persaingan tersebut, dimana suatu perusahaan dituntut untuk mampu 
menghadapi berbagai kendala yang timbul dalam mengelola bisnis usaha pemasarannya, juga untuk menjamin perusahaan yang bersangkutan supaya dapat beroperasi dengan manajemen yang efektif dan efisien.

Diantara sekian banyak Kecamatan di Semarang, Kecamatan Tembalang menjadi salah satu Kecamatan dengan perkembangan pelanggan TV kabel yang cukup signifikan di antara yang lainnya, baik Indovision, Indihome, MNC, My Republic, dan lain-lain. Hal ini didukung dengan beberapa kawasan perumahan dan juga perantau yang banyak berdomisili di Kecamatan Tembalang baik mahasiswa maupun pekerja, serta bahwa Kecamatan Tembalang berada di posisi yang strategis menuju jalur kota.

Salah satu strategi pemasaran untuk mempertahankan loyalitas pelanggan yakni dengan menerapkan Customer Relationship Management (CRM) agar membangun hubungan baik dengan para konsumenyang mereka miliki. Menurut Amstrong (2007) Customer Relationship Management adalah seluruh proses dalam membangun dan menjaga hubungan yang menguntungkan dengan pelanggan melalui pengantaran nilai (value) dan kepuasan (satisfaction) yang tinggi bagi pelanggan. Menurut Amstrong (2007) ini mencakup seluruh aspek dalam mendapatkan, menjaga, dan meningkatkan jumlah pelanggan. Definisi yang lain pada Peelen (2005) menyebutkan bahwa Customer Relationship Management adalah sebuah proses yang meliputi semua aspek dalam mengidentifikasi pelanggan,menciptakan pengetahuan tentang pelanggan, membangun hubungan dengan pelanggan, dan membentuk pendapat pelanggan tentang organisasi dan produknya. Menurut Peelen (2005), di dalam definisi ini tidak dibahas mengenai peran teknologi dalam Customer Relationship Management. Definisi ini lebih memperhatikan pelanggan dan sasaran yang ingin diraih (vis-a-vis the customer).

Tak bisa kita pungkiri bila kepuasan konsumen menjadi salah satu fokus utama para pengusaha maupun pelaku pasar ketika menawarkan sebuah produk. Tanpa memelihara loyalitas mereka dan tanpa adanya hubungan baik antara customer dengan pihak perusahaan, bisa dipastikan bila pemasaran yang dijalankan kurang bekerja secara maksimal dan roda bisnis yang dijalankan belum berhasil memenangkan persaingan pasar yang semakin hari semakin ramai. Karenanya, sebuah perusahaan membutuhkan strategi Customer Relationship Management untuk mempertahankan kejayaan bisnisnya dalam jangka waktu yang lama.

Pelanggan bukanlah orang yang tergantung pada kita, tetapi kita yang tergantung padanya, orang yang membawa kita ke keinginannya dan orang yang teramat penting yang harus dipuaskan (Gaspersz, 2002). Kepuasan adalah respon atau tanggapan konsumen mengenai pemenuhan kebutuhan. Kepuasan merupakan penilaian mengenai ciri atau keistimewaan produk atau jasa, atau produk itu sendiri, yang menyediakan tingkat kesenangan konsumen berkaitan dengan pemenuhan kebutuhan konsumsi konsumen (Zeithaml dan Bitner, 2000). Kepuasan konsumen adalah sejauh mana anggapan kinerja produk memenuhi harapan pembeli. Bila kinerja produk lebih rendah ketimbang harapan pelanggan, maka pembelinya merasa puas atau amat gembira (Kotler dan Armstrong, 2001). Kepuasan konsumen merupakan suatu tanggapan perilaku konsumen berupa evaluasi purna beli terhadap suatu barang atau jasa yang dirasakannya dibandingkan dengan harapan konsumen. Kepuasan konsumen ini sangat tergantung pada persepsi dan harapan konsumen itu sendiri. Faktor-faktor yang mempengaruhi persepsi dan harapan konsumen ketika melakukan pembelian suatu barang atau jasa adalah kebutuhan dan keinginan yang dirasakan oleh konsumen tersebut pada saat melakukan pembelian suatu barang atau jasa, pengalaman masa lalu ketika mengkonsumsi barang atau jasa tersebut serta pengalaman teman-teman yang telah mengkonsumsi barang atau jasa tersebut dan periklanan. Di dalam lingkungan yang kompetitif, indikator yang dapat menunjukkan kepuasan konsumen adalah apakah konsumen tersebut akan membeli kembali dan menggunakan produk tersebut di waktu yang akan datang. 
Loyalitas pelanggan adalah kesediaan pelanggan untuk terus berlangganan pada sebuah perusahaan dalam jangka panjang, dengan membeli dan menggunakan barang dan jasanya secara berulang-ulang dan lebih baik lagi secara eksklusif, dan dengan suka rela merekomendasikan produk perusahaan tersebut kepada teman-teman dan rekanrekannya (Lovelock \& Wright, 2007). Loyalitas akan berlanjut hanya sepanjang pelanggan merasakan bahwa pelanggan menerima kualitas yang lebih baik dibandingkan dengan tawaran dari perusahaan lain. Seorang pelanggan, jika merasa puas dengan nilai yang diberikan oleh produk atau jasa, sangat besar kemungkinannya menjadi pelanggan dalam waktu yang lama. Kelangsungan hidup dari bisnis yang dijalankan ditentukan oleh bagaimana cara yang digunakan oleh suatu perusahaan dalam rangka memuaskan kebutuhan para pelanggan sesuai dengan apa yang diharapkan bahkan melampauinya. Mempertahankan pelanggan yang sudah ada lebih sulit dibandingkan mencari pelanggan baru yang tentunya memakan biaya yang lebih tinggi seperti memasang promosi atau iklan yang lebih sering.

Untuk mengetahui apakah ada pengaruh antara Customer Relationship Management (CRM), kepuasan dan loyalitas seperti uraian diatas maka dirumuskan beberapa pertanyaan penelitian sebagai berikut: (1) Apakah kepuasan pelanggan berpengaruh terhadap loyalitas pelanggan?; (2) Apakah Customer Relationship Management (CRM) berpengaruh terhadap loyalitas pelanggan?; (3) Apakah Customer Relationship Management (CRM) dan kepuasan pelanggan berpengaruh terhadap loyalitas pelanggan?; (4) Apakah Customer Relationship Management (CRM) berpengaruh terhadap loyalitas pelanggan dengan kepuasan pelanggan sebagai variabel intervening?

\section{Kerangka Teori}

Pemasaran

Kotler (2009) mendefinisikan pemasaran merupakan salah satu kegiatan yang menunjang perusahaan dalam mencapai keberhasilan. Pemasaran merupakan proses sosial dan manajerial dengan seseorang ataupun kelompok dimana mereka memperoleh apa yang mereka butuhkan dan inginkan melalui penciptaan dan pertukaran produk dan nilai. Pada dasarnya, pemasaran memiliki fungsi yang lebih daripada lainnya bagi perusahaan, yakni berhubungan dengan pelanggan.

\section{Customer Relationship Management (CRM)}

Menurut Buttle (2007) Customer Relationship Management (CRM) adalah strategi inti dalam bisnis yang mengintegrasikan proses-proses dan fungsifungsi internal dengan semua jaringan eksternal untuk menciptakan serta mewujudkan nilai bagi para konsumen sasaran secara profitabel. Manajemen hubungan pelanggan (customer relationship marketing) adalah kegiatan keseluruhan perusahaan untuk memperoleh dan mempertahankan pelanggan. Customer Relationship Management (CRM) mengenali pelanggan sebagai inti dari bisnis dan bahwa keberhasilan perusahaan tergantung pada hubungan dengan pelanggan yang dikelola secara efektif.

\section{Kepuasan Pelanggan}

Kepuasan pelanggan terhadap pembelian tergantung pada kinerja nyata sebuah produk, relatif terhadap harapan pembeli (Kotler, 2009). Kesenangan yang dialami oleh pelanggan dapat menciptakan kelekatan emosional untuk suatu produk dan jasa, bukan hanya preferensi rasional, hal ini juga menciptakan loyalitas pelanggan yang tinggi. Kepuasan pelanggan merupakan tindakan dimana kinerja anggapan produk sesuai dengan ekspektasi pembelian (Kotler, 2009).

\section{Loyalitas Pelanggan}

Loyalitas pelanggan adalah kesediaan pelanggan untuk terus berlangganan pada sebuah perusahaan dalam jangka panjang, dengan membeli dan menggunakan barang dan jasanya secara berulang-ulang dan lebih baik lagi secara eksklusif, dan dengan suka rela merekomendasikan produk perusahaan 
tersebut kepada teman-teman dan rekanrekannya (Lovelock \& Wright, 2007). Loyalitas menunjukkan kondisi dari durasi waktu tertentu dan mensyaratkan bahwa tindakan pembelian terjadi tidak kurang dari dua kali (Griffin, 2003). Loyalitas akan belanjut hanya sepanjang pelanggan merasakan bahwa pelanggan menerima kualitas yang lebih baik dibandingkan dengan tawaran dari perusahaan lain.

Hipotesis

Hipotesis merupakan jawaban sementara terhadap rumusan masalah dalam penelitian (Sugiyono, 2010). Berdasarkan tinjauan pustaka atau kerangka penelitian seperti yang telah diuraikan, maka hipotesis dalam penelitian ini dapat dirumuskan sebagai berikut:

Hipotesis 1: Terdapat pengaruh yang signifikan antara Customer Relationship Management (CRM) terhadap kepuasan pelanggan

Hipotesis 2: Terdapat pengaruh yang signifikan antara kepuasan pelanggan terhadap loyalitas pelanggan

Hipotesis 3: Terdapat pengaruh yang signifikan antara Customer Relationship Management (CRM) terhadap loyalitas pelanggan

Hipotesis 4: Terdapat pengaruh yang signifikan antara Customer Relationship Management (CRM) dan kepuasan pelanggan terhadap loyalitas pelanggan

Hipotesis 5: Terdapat pengaruh yang signifikan antara Customer Relationship Management (CRM) terhadap loyalitas pelanggan dengan kepuasan pelanggan sebagai variabel intervening

\section{Metode}

Tipe penelitian yang digunakan dalam penelitian ini adalah tipe eksplanatory research yaitu jenis penelitian yang membahas mengenai pengaruh variabel independen (CRM), terhadap variabel dependen (loyalitas pelanggan) dengan variabel intervening (kepuasan) dan menguji hipotesis yang telah dirumuskan (Sugiyono, 2006).

Dalam penelitian ini, penulis menggunakan teknik Non-probability Sampling yaitu purposive sampling dan accidental sampling. Purposive sampling yaitu teknik penentuan sampel dengan pertimbangan tertentu sedangkan accidental sampling yaitu teknik penentuan sampel berdasarkan kebetulan. Jadi, peneliti akan memberikan kuesioner kepada responden yang memenuhi kriteria sebagai berikut: (a) Responden adalah pengguna/pelanggan atau pernah menggunakan layanan TV berbayar Indovision lebih dari 1 tahun; (b) Responden adalah masyarakat yang mengetahui dan pernah mendapatkan layanan-layanan TV berbayar Indovision; (c) Responden berusia 18 tahun ke atas dengan pertimbangan seseorang yang berusia di atas 18 tahun sudah di anggap dewasa dan mampu berpikir secara logis; (d) Berdomisili di Kecamatan Tembalang dan bersedia mengisi kuesioner dan diwawancarai.

Menurut Cooper (1996), formula dasar dalam menentukan ukuran sampel untuk populasi yang tidak teridentifikasi secara pasti, jumlah sampel ditentukan secara langsung sebesar 100. Jumlah sampel 100 sudah memenuhi syarat suatu sampel dikatakan representative. Sejumlah 100 orang responden yang cukup mewakili untuk diteliti dan diharapkan dapat memenuhi distribusi normal (Hair, et al., 1998).

\section{Hasil dan Pembahasan}

Customer Relationship Management (CRM) memiliki tingkat keeratan hubungan yang kuat terhadap kepuasan pelanggan Indovision, yaitu sebesar 0,616 karena terletak pada interval 0,60-0,799. Dilihat dari 
nilai koefisien determinasi, kontribusi yang diberikan variabel Customer Relationship Management (CRM) terhadap kepuasan pelanggan sebesar $40,3 \%$. Menurut Sutisna (2002) yaitu: Jika konsumen menjadi loyal terhadap satu merek tertentu disebabkan oleh kualitas produk yang memuaskan penyebabnya adalah kualitas pelayanan yang diberikan (CRM). Customer Relationship Management (CRM) berbicara mengenai bagimana memanajemeni hubungan dengan pelanggan, dan untuk bisa memanajemeni hubungan dengan pelanggan secara baik, tepat dan benar, tentunya perusahaan harus tahu terlebih dahulu siapa pelanggannya. Berdasarkan teori tersebut, maka dapat disimpulkan bahwa Customer Relationship Management (CRM) yang dilakukan oleh perusahaan dapat menciptakan kepuasan pelanggan. Terdapat pengaruh positif dan signifikan antara Customer Relationship Management (CRM) terhadap kepuasan pelanggan, dilihat dari nilai analisis koefisien regresinya sebesar 0,349 dan nilai t hitung $(8,187)>\mathrm{t}$ tabel $(1,984)$ dengan taraf signifikansi kurang dari 0,05 .

Kepuasan pelanggan memiliki tingkat keeratan hubungan yang cukup kuat (sedang) terhadap loyalitas pelanggan, yaitu sebesar 0,586 karena terletak pada interval $0,40-$ 0,599 . Dilihat dari nilai koefisien determinasi, kontribusi yang diberikan variabel kepuasan terhadap loyalitas pelanggan sebesar $34,1 \%$. Menurut Lupiyoadi dan Hamdani (2006) menyatakan bahwa kepuasan berpengaruh terhadap loyalitas pelanggan. Tingkat kepuasan pelanggan yang tinggi dapat meningkatkan loyalitas pelanggan dan mencegah perputaran pelanggan, serta meningkatkan efektivitas iklan dan meningkatkan reputasi bisnis. Terdapat pengaruh positif dan signifikan antara kepuasan terhadap loyalitas pelanggan, dilihat dari nilai analisis koefisien regresinya sebesar 0,591 dan nilai $\mathrm{t}$ hitung $(7,210)>\mathrm{t}$ tabel $(1,9845)$ dengan taraf signifikansi kurang dari 0,05 .

Customer Relationship Management (CRM) memiliki tingkat keeratan hubungan yang cukup kuat terhadap loyalitas pelanggan, yaitu sebesar 0,588 karena terletak pada interval $0,40-0,599$. Dilihat dari nilai koefisien determinasi, kontribusi yang diberikan variabel harga terhadap loyalitas pelanggan sebesar 33,7\%. Menurut Buttle (2004) Manajemen hubungan pelanggan atau Customer Relationship Management (CRM ) adalah strategi inti dalam bisnis yang mengintegrasikan prosesproses dan fungsi-fungsi internal dengan semua jaringan eksternal untuk menciptakan serta mewujudkan nilai bagi para konsumen sasaran secara profitabel. Banyak perusahaan tengah terfokus pada kegiatan perawatan pelanggan mereka. Banyak cara dan program dibuat untuk mendapatkan loyalitas pelanggan, karena pada akhirnya loyalitas pelanggan ini akan meningkatkan keuntungan perusahaan. Terdapat pengaruh positif dan signifikan antara Customer Relationship Management (CRM) terhadap loyalitas pelanggan, dilihatdari nilai analisis koefisien regresinya sebesar 0,325 dan nilai $\mathrm{t}$ hitung $(7,227)>t$ tabel $(1,9845)$ dengan taraf signifikansi kurang dari 0,05 .

\section{Customer Relationship Management} (CRM) dan kepuasan pelanggan memiliki tingkat keeratan asosiasi (hubungan) linear yang kuat terhadap loyalitas pelanggan, yaitu sebesar 0,648 , karena terletak pada interval $0,60-0,799$. Dilihat dari nilai koefisien determinasi, kontribusi yang diberikan Customer Relationship Management (CRM) dan kepuasan pelanggan terhadap loyalitas pelanggan sebesar $41,7 \%$.Banyak perusahaan yang memanfaatkan Customer Relationship Management (CRM) untuk menjalin hubungan erat dengan pelanggan, dengan memanfaatkan Customer Relationship Management (CRM), perusahaan akan mengetahui apa yang diharapkan dan diperlukan pelanggannya sehingga akan tercipta ikatan emosional yang mampu menciptakan hubungan bisnis yang erat dan terbuka serta komunikasi dua arah atau timbal balik di antara mereka, dengan demikian kesetiaan pelanggan dapat dipertahankan dan tidak mudah berpindah ke lain produk dan merek, terlebih produk dan merek perusahaan pesaing (Rizkiyani, 2013; Pambudi, 2014). Terdapat pengaruh positif dan signifikan antara CustomerRelationship Management (CRM) dan kepuasan pelanggan terhadap loyalitas pelanggan, dilihat dari nilai analisis koefisien regresi bergandanya yakni sebesar 0,201 untuk 
Customer Relationship Management (CRM) dan sebesar 0,358 untuk kepuasan pelanggan, serta nilai $\mathrm{F}$ hitung $(35,687)>\mathrm{F}$ tabel $(3,09)$ ini menyatakan Customer Relationship Management (CRM) dan kepuasan pelanggan secara bersama-sama mempunyai pengaruh signifikan terhadap loyalitas pelanggan.

Pengaruh variabel Customer Relationship Management (CRM) terhadap variabel loyalitas melalui variabel kepuasan terbukti. Hal ini dibuktikan melalui penelitian dimana nilai t statistik adalah sebesar 3,188 yang lebih besar dari t tabel yaitu 1,984 yang menunjukkan bahwa, terdapat pengaruh antara Customer Relationship Management (CRM) terhadap loyalitas melalui kepuasan. Nilai $p$-value $(0,00311)<$ taraf signifikansi $(0,05)$, maka pengaruh yang diberikan oleh variabel intervening tersebut signifikan.

\section{Kesimpulan}

Berdasarkan hasil penelitian terhadap 100 pelanggan Indovision di Kecamatan Tembalang mengenai pengaruh Customer Relationship Management (CRM) terhadap loyalitas pelanggan dengan kepuasan pelanggan sebagai variabel intervening, dapat diambil beberapa kesimpulan.

Terdapat pengaruh antara variabel Customer Relationship Management (CRM) terhadap kepuasan pelanggan, hal ini ditunjukkan dengan perhitungan dimana $\mathrm{t}$ hitung $(8,187)$ lebih besar dibandingkan $t$ tabel yaitu $(1,984)$ dengan taraf signifikansi kurang dari 0,05 sehingga dapat dikatakan bahwa hipotesis 1 diterima. Customer Relationship Management (CRM) juga memiliki tingkat keeratan hubungan yang kuat terhadap kepuasan pelanggan Indovision, yaitu sebesar 0,616 karena terletak pada interval koefisien korelasi 0,600,799 .

Terdapat pengaruh antara variabel kepuasan pelanggan terhadap loyalitas pelanggan, hal ini ditunjukkan dengan perhitungan dimana t hitung $(7,210)$ lebih besar dibandingkan $\mathrm{t}$ tabel yaitu $(1,984)$ dengan taraf signifikansi kurang dari 0,05 sehingga dapat dikatakan bahwa hipotesis 2 diterima. Kepuasan pelanggan juga memiliki tingkat keeratan hubungan yang cukup kuat (sedang) terhadap loyalitas pelanggan, yaitu sebesar 0,586 karena terletak pada interval $0,40-0,599$.

Terdapat pengaruh antara variabel Customer Relationship Management (CRM) terhadap loyalitas pelanggan, hal ini ditunjukkan dengan perhitungan dimana $\mathrm{t}$ hitung $(7,227)$ lebih besar dibandingkan $t$ tabel yaitu $(1,984)$ dengan taraf signifikansi kurang dari 0,05 sehingga dapat dikatakan bahwa hipotesis 3 diterima. Customer Relationship Management (CRM) juga memiliki tingkat keeratan hubungan yang cukup kuat terhadap loyalitas pelanggan, yaitu sebesar 0,588 karena terletak pada interval 0,40-0,599.

Terdapat pengaruh antara variabel Customer Relationship Management (CRM) dan kepuasan pelanggan terhadap loyalitas pelanggan, hal ini ditunjukkan dengan perhitungan dimana $\mathrm{F}$ hitung $(35,687)$ lebih besar dibandingkan $\mathrm{F}$ tabel yaitu $(3,09)$ dengan taraf signifikansi kurang dari 0,05 sehingga dapat dikatakan bahwa hipotesis 4 diterima. Customer Relationship Management (CRM) dan kepuasan pelanggan juga memiliki tingkat keeratan asosiasi (hubungan) linear yang kuat terhadap loyalitas pelanggan, yaitu sebesar 0,648 karena terletak pada interval $0,60-0,799$ Terdapat pengaruh antara variabel variabel Customer Relationship Management (CRM) terhadap loyalitas pelanggan melalui kepuasan pelanggan, hal ini ditunjukkan dengan perhitungan dimana $t$ statistik $(3,188)$ lebih besar dibandingkan $t$ tabel yaitu $(1,984)$ dengan taraf signifikansi kurang dari 0,05 dan Nilai $p$-value $(0,00311)<$ taraf signifikansi $(0,05)$ maka pengaruh yang diberikan oleh variabel intervening tersebut signifikan sehingga dapat dikatakan bahwa hipotesis 5 diterima.

\section{Saran}

Berdasarkan kesimpulan yang telah dijabarkan di atas, maka peneliti mengajukan 
saran-saran untuk melengkapi hasil penelitian.

Untuk membuat Customer Relationship Management (CRM) yang dilakukan oleh Indovision lebih baik dan berkualitas daripada merek lain, perusahaan sebaiknya meningkatkan pelayanan terhadap pelanggan dan mempercepat proses keluhan.

Untuk membuat harapan pelanggan Indovision mengenai produknya sudah sesuai dengan kenyataan, perusahaan disarankan lebih memperhatikan kotak kritik dan saran yang ditaruh di kantor Indovision cabang Semarang serta bisa ditambahkan di dalam website Indovision melalui email. Pelanggan Indovision dapat memberi kritik ataupun saran dan perusahaan dapat memperbaikinya sehingga produknya bisa sesuai dengan harapan pelanggan.

Untuk dapat membuat Indovision sebagai produk pilihan utama bagi pelanggan, perusahaan disarankan tetap mempertahankan Customer Relationship Management (CRM) yang sudah ada serta menjaga kualitas Indovision.

\section{Daftar Referensi}

Akhmad, Rifai. (2013). Analisis Konsentrasi Kepuasan Konsumen Pengguna TV Kabel di Banjarmasin. Banjarmasin. Jurnal Kindai, Volume 9, Nomor 3, JuliSeptember.

Barnes, James G. (2003). Secrets of Customer Relationship Management. Yogyakarta: Penerbit Andi.

Cooper, D. R. dan Emory, C. W. (1996). Metode Penelitian Bisnis. Jakarta: Erlangga.

Dharmesta, Handoko. (1997). Manajemen Pemasaran: Analisis Perilaku Pemasaran. Yogyakarta: Penerbit BPFE.

Ghozali, Imam. (2007). Aplikasi Analisis Multivariate dengan Program SPSS. Semarang: Universitas Diponegoro.
Griffin, Jill. (2003). Customer Loyalty: Menumbuhkan dan Mempertahankan Pelanggan. Jakarta, Airlangga.

Gultinan, Agus M. (1992). Manajemen Pemasaran: Strategi Program. Jakarta: Erlangga.

Hurriyati, Ratih. (2005). Bauran Pemasaran dan Loyalitas Konsumen. Bandung: Alfabeta.

Kotler, Philip. (1994). Manajemen Pemasaran Buku Dua Edisi Ke delapan. Jakarta: Prenhallindo.

Kotler, Philip. (2001). Manajemen Pemasaran. Jilid II Edisi 10. Jakarta: Penerbit PT Prenhallindo.

Kotler, Philip. (2009). Manajemen Pemasaran, Jilid 1 Edisi 13. Jakarta: Erlangga.

Kotler, Philip, dan Gary Armstrong. (2004). Dasar-Dasar Pemasaran, Edisi kesembilan, Jilid 1, dialihbahasakan oleh Alexander Sindoro, Jakarta: Penerbit Indeks.

Kotler, dan Amstrong, G. (2001). PrinsipPrinsip Pemasaran, Jilid 2. Alih Bahasa, Benyamin Molan. Jakarta: PT.Prenhallindo.

Kotler, Philip dan Gary Armstrong. (1997). Dasar-dasar Pemasaran. Jakarta: Prenhallindo.

Kotler, Phillip. (2005). Manajemen Pemasaran: Analisis, Perencanaan, Implementasi dan Kontrol, Edisi $\mathrm{Ke}$ sebelas. Alih Bahasa, Hendra Teguh. Jakarta: PT. Prehallindo.

Limsanny. (2009). Strategi peningkatan loyalitas konsumen dengan diferensiasi. Jurnal Psikologi, Volume 7, Nomor 1.

Lupiyoadi, Hamdani. (2006). Manajemen Pemasaran Jasa, Edisi Kedua. Jakarta: Penerbit Salemba Empat. 
Lupiyoadi, Hamdani. (2009). Manajemen Pemasaran Jasa. Jakarta: Salemba Empat.

Lutfi. (2016). Analisis Corporate Social Responsibility Sebagai Pembentuk Citra Perusahaan dan Pengaruhnya Terhadap Loyalitas Pelanggan Pada PT Pos Indonesia (Persero). Semarang: Fakultas Ilmu Sosial dan Ilmu Politik Universitas Diponegoro.

Masburoh. (2003). Membangun Kepuasan Konsumen dan Akses Loyalitas. Benefit, Vol. 7 No. 2.

McCharty, E. Jerome \& William D. Perreault, Jr. (1993). Dasar - Dasar Pemasaran. Jakarta: Erlangga

Nawangsari, S., \& Budiman. (2008). Pengaruh kepuasan konsumen terhadap Loyalitas Merek. Jurnal Psikologi, Volume 1, No. 2, Juni 2008.

Ngatno. (2015). Analisis Data Variabel Mediasi dan Moderasi Dalam Riset Bisnis Dengan Program SPSS. (T. Farishma, Ed.). Yogyakarta: Popup.

Nina, Suharyono dan Edy. (2016). Pengaruh Customer Relationship Management (CRM) Terhadap Kepuasan dan Loyalitas Pelanggan (Survei Pada Pelanggan PT Astra Internasional, TbkTso Auto 2000 Cabang Denpasar). Jurnal Administrasi Bisnis (JAB), Vol. 30 Nomor 1, Januari.

O'Brian, James A. (2002). Customer Relationship Management, Management Information System: Managing Information Technology in the EBusiness Enterprise. McGraw-Hill Higher Education, pp.128-131.

Samuel, H., \& Foedjiawati. (2005). Pengaruh Kepuasan Konsumen Terhadap Kesetian Merek (Studi Kasus Restoran the Prime Steak \& Ribs Surabaya). Jurnal Manajemen \& Kewirausahaan, Volume 7, Nomor 1, 74-82.
Silvida. (2016). Analisis Pengaruh Customer Relationship Marketing dan Layanan Purna Jual Terhadap Kepuasan Pelanggan (Studi pada Komunitas Honda Mobilio Region Lampung). Lampung: Fakultas Ilmu Sosial dan Ilmu Politik, Universitas Lampung.

Sugiyono. (2010). Metode Penelitian Bisnis. Bandung: ALFABETA.

Sugiyono. (2014). Metode Penelitian Kuantitatif, Kualitatif, dan $R \& D$. Bandung: ALFABETA.

Sumarahadi. (2000). Analisis Bisnis Manajemen dan Pemasaran. Yogyakarta: Penerbit Liberty.

Sutedjo, Budi dan PhIip. (2002). I-CRM: Membina Relasi dengan Pelanggan. Yogyakarta: Penerbit Andi.

Sutisna. (2003). Perilaku Konsumen \& Komunikasi Pemasaran. Cetakan ketiga. Bandung: Rosdakarya.

Swastha Dh, Basu. (2001). Manajemen Pemasaran Modern, Edisi 2. Yogyakarta: Penerbit Liberty.

Tjiptono, Fandy. (2009). Strategi Pemasaran. Yogyakarta: ANDI.

Tjiptono, Fandy. (2007). Manajemen Jasa, edisi IV. Yogyakarta: Penerbit ANDI.

Utami, Christina W. (2010). Manajemen Ritel: Strategi dan Implementasi Operasional Bisnis Ritel Modern di Indonesia. Jakarta: Salemba Empat.

Victoria, Ruswanti, Farichah. (2014). Pengaruh Layanan Purna Jual Terhadap Kepuasan Pelanggan Pada PT Surya Toto Indonesia. Journal of Business and Banking, Volume 4, Nomor 2, Pp153164.

Widjaja, A. Tunggal. (2000). Konsep Data Customer Relationship Management (CRM). Jakarta: Harvarido. 
Yuda, P. (2010). Pengaruh kepercayaan .http://quantpsy.org/sobel/sobel.htm merek terhadap loyaliyas merek. Jurnal Ilmu Manajemen Volume 7, Nomor 1. 